\title{
Paleomagnetic and rock magnetic studies of Cretaceous rocks in the Eumsung basin, Korea
}

\author{
Seong-Jae Doh ${ }^{1}$, Dong-Woo Suk $^{2}$, and Bang-Yeon Kim ${ }^{1}$ \\ ${ }^{1}$ Department of Earth and Environmental Sciences, Korea University, Seoul, 136-701, Korea \\ ${ }^{2}$ Department of Earth and Marine Sciences, Hanyang University, Ansan, 425-791, Korea
}

(Received August 15, 1998; Revised November 3, 1998; Accepted March 29, 1999)

\begin{abstract}
Paleomagnetic results are obtained from 41 sites from the Chopyeong Formation within the Eumsung basin, located along the northern boundary of the Ogcheon Belt, Korea. The Chopyeong Formation, deposited in early Cretaceous, yields the mean direction of $D / I=347.8^{\circ} / 57.3^{\circ}\left(k=92.8, \alpha_{95}=2.5^{\circ}\right)$ before tilt correction, and $D / I=0.7^{\circ} / 61.7^{\circ}\left(k=19.6, \alpha_{95}=5.5^{\circ}\right)$ after tilt correction. The parameter estimating fold test and the stepwise unfolding test of the red bed and greenish mudstone of the Chopyeong Formation yield the maximum value of $k$ at $21.9 \%$ and at $20 \%$ untilting, respectively, indicating that the remanence whose mean direction of $D / I=350.8^{\circ} / 57.9^{\circ}\left(k=177.9, \alpha_{95}=1.8^{\circ}\right)$ at $20 \%$ untilting was acquired during or after tilting of the strata. The comparison of the paleomagnetic pole from the Chopyeong Formation with those from the Youngdong basin and the Euiseong area in the Gyeongsang basin indicates that the remanence was acquired during late Cretaceous to early Tertiary. Electron microscope observations and rock magnetic experiments show that secondary hematite and magnetite grains of single domain to pseudo-single domain size were authigenically formed under the influence of fluids presumably triggered by the igneous activities, thus confirm the chemical remagnetization.

It is revealed that the age of the granite in the east is Jurassic because the mean direction of the east granite $\left(D / I=347.0^{\circ} / 47.7^{\circ}, k=40.2, \alpha_{95}=3.6^{\circ}\right)$ is similar to the Jurassic direction of Korea Peninsula. The age of the granite in the west, however, is left undetermined whether it is Cretaceous or Jurassic because of the weak intensity and instability of the remanence of the granite during demagnetization treatments.
\end{abstract}

\section{Introduction}

Paleomagnetism is a useful tool to estimate the age of rocks and to detect tectonic disturbance that might cause deflection of paleomagnetic directions. Paleomagnetic data are also used to reconstruct the large scale tectonic movement. In Korea, many paleomagnetic studies were carried out for Cretaceous rocks mainly from the Gyeongsang basin in the southeastern part of the Korea Peninsula. Cretaceous basins in South Korea can be sorted into three groups by their areal distributions. The Gyeongsang basin is composed of three sub-basins and occupies the largest area compared to other Cretaceous basins. The second one comprises small-sized basins, compared to the Gyeongsang basin, and is distributed along the Ogcheon Belt. The third group consists of basins located in the Kyeonggi massif parallel to the boundary of the Ogcheon Belt. The Eumsung basin, occupying along the northern boundary of the Ogcheon Belt, is mainly composed of Cretaceous sedimentary rocks within strike-slip fault system (Fig. 1).

A few paleomagnetic studies for Cretaceous rocks from basins other than the Gyeongsang basin have been carried out (Lee et al., 1992; Cho, 1994; Won et al., 1994), compared to many paleomagnetic studies for the Gyeongsang basin (e.g., Min et al., 1982; Otofuji et al., 1982, 1986; Kim

Copy right $(\mathrm{C})$ The Society of Geomagnetism and Earth, Planetary and Space Sciences (SGEPSS); The Seismological Society of Japan; The Volcanological Society of Japan; The Geodetic Society of Japan; The Japanese Society for Planetary Sciences. and Cheong, 1986; Lee et al., 1987; Kim and Kim, 1991; Kim et al., 1993; Doh and Kim, 1994; Doh et al., 1994). Only one paleomagnetic study for the Eumsung basin has been done by Lee et al. (1992). In that study, results from just 5 samples of 1 site were reported, which can hardly be considered as representative directions of the strata in the Eumsung basin. In this study, paleomagnetic results from Cretaceous rocks in the Eumsung basin are presented by comparing the results with those from the Gyeongsang basin and other Cretaceous basins in order to clarify the magnetic and tectonic characteristics of the basin.

In terms of the age of granites in the study area, Cheong et al. (1976) suggested that the granite in the eastern part of the basin is Jurassic in age, and that of the granite in the west is Cretaceous. However, Chun et al. (1994) recently argued that the granite in the west to the basin formed in Jurassic. A paleomagnetic investigation of the granites in the Eumsung basin is carried out to constrain the age of the granites utilizing the timing of the magnetization of the granites.

\section{Geologic Setting}

The Eumsung basin is a pull-apart basin formed between left-stepping sinistral "master" strike slip faults, and filled with Cretaceous sedimentary rocks which were named as the Chopyeong Formation (Chun et al., 1994). Precambrian gneiss and Jurassic granite comprise the basement of the basin and volcanic rocks are distributed along the eastern boundary of the basin (Lee and Kim, 1971; Cheong et al., 


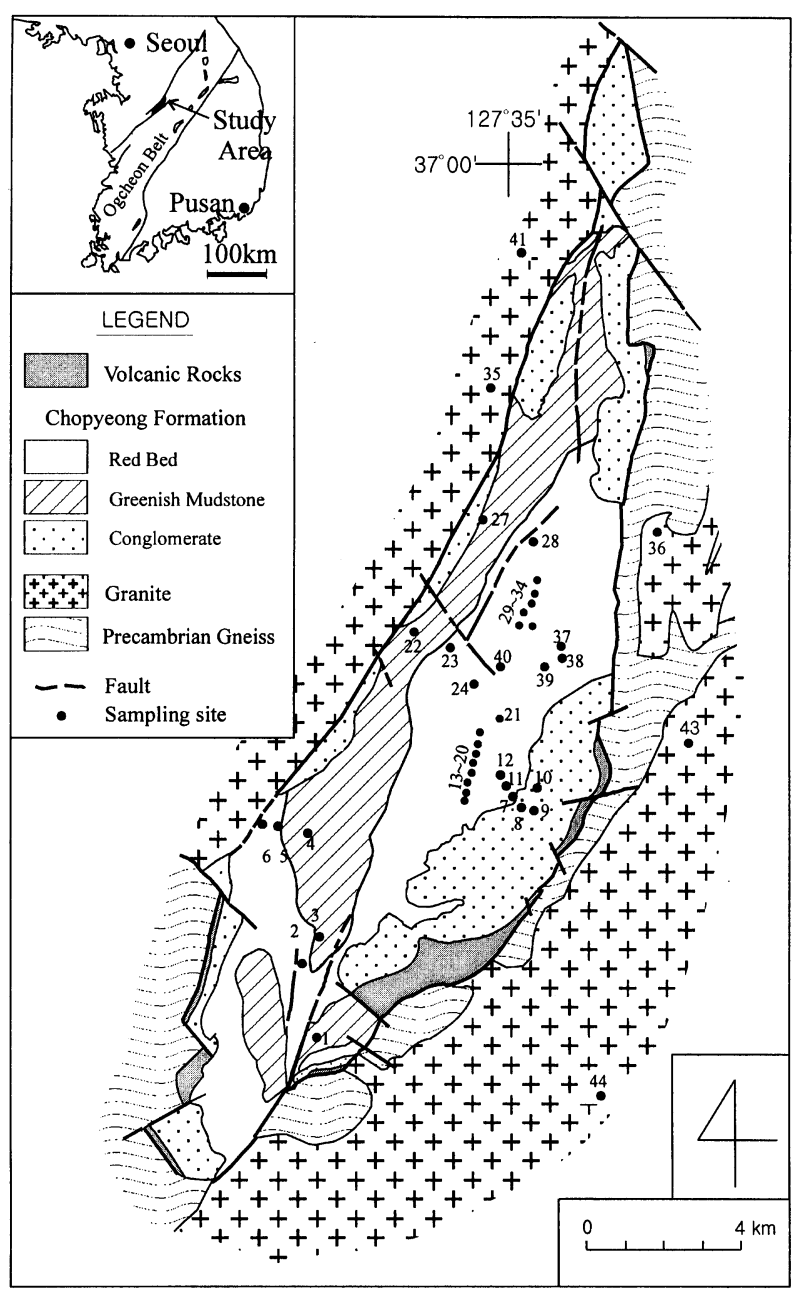

Fig. 1. Geologic map of the Eumsung basin, showing the locations of the paleomagnetic sampling sites (after Chun et al., 1994).

1976; Kang et al., 1980; Lee et al., 1989).

The ages of the granites in the eastern and the western parts of the basin were thought to be Jurassic and Cretaceous, respectively (Cheong et al., 1976). However, recently Chun et al. (1994) claimed that the age of the granite in the western part is Jurassic, because of cataclastic texture at the fault contact of the granite with sedimentary rocks and presence of perthite, a feldspar mineral formed in a plutonic rock by slow cooling of magma, in sandstones collected from central to western part of the basin. The granite outside the western boundary, therefore, must be the source rock of the sedimentary rocks in the western part of the basin and predate the Cretaceous sedimentary rocks.

The Chopyeong Formation consists of various sedimentary rocks, that can be divided into 3 lithofacies; conglomerate facies, greenish mudstone facies, and purplish mudstone facies (Fig. 1). Conglomerate facies is confined along the margin of the basin, and the inner part of the basin is filled with greenish and purplish mudstones, containing lenticular beds of sandstone and clasts-bearing sandstones. Microfossils of Charophytes are found only in greenish mudstone facies (Choi et al., 1995). This succession is considered to be formed in a stream dominated alluvial to lacustrine de- positional environment. Sediments are thought to be mainly derived from the nearby rocks, such as Precambrian gneiss, Jurassic granite, and syn-depositional volcanic rocks (Chun et al., 1994).

After the formation of sedimentary basin, the strata have been deformed three times (Chun et al., 1994). The first deformation was caused by the sinistral strike-slip fault which reactivated the master faults and adjacent faults of the same attitude in the basin. The second and third deformations were caused by the NW-SE and the ENE-WSW sinistral strike-slip fault which cut through the master faults. The folds developed in the sedimentary rocks were formed by the sinistral strike-slip faulting and tilting along the master faults and by the similarly oriented faults. The folds are wide open and have the NNE to NE trend with low angle of plunging axis in the central part of the basin and NE-SW trend in the marginal parts of the master faults.

\section{Field and Laboratory Methods}

In the field, samples were cored with a gasoline-powered portable drill and oriented with magnetic and sun compasses. There were no significant differences between magnetic and sun compass azimuths. 765 samples from 41 sites were collected: 31 sites from red bed (purplish mudstone facies and interlayered siltstone beds in conglomerate facies), 5 sites from greenish mudstone, and 5 sites from granite (Fig. 1).

In the laboratory, samples were cut into $2.2 \mathrm{~cm}$ long cylinders. Remanent magnetization of specimens was measured using a Molspin spinner magnetometer. To determine suitable demagnetization method for the specimens of each site, pilot samples were demagnetized either by alternating field (AF) demagnetization or by thermal demagnetization. AF demagnetization was performed at the field strength of 5-30 $\mathrm{mT}$ with $5 \mathrm{mT}$ interval and 40-90 mT with $10 \mathrm{mT}$ interval using a Molspin AF demagnetizer. Thermal demagnetization was performed at 100, 200,300,350, 400, 450, 500, and for temperature range of $520-700^{\circ} \mathrm{C}$ with $20^{\circ} \mathrm{C}$ intervals using an ASC Scientific thermal demagnetizer (model TD-48). To monitor possible chemical changes of magnetic carriers on heating, magnetic susceptibility was measured at each step of thermal demagnetization using a Bartington magnetic susceptibility meter (model MS2). The samples were stored in mu-metal boxes to prevent from acquisition of viscous remanence by the external magnetic field. The remaining specimens were demagnetized using the suitable method for each site. The orthogonal vector diagrams (Zijderveld, 1967) for paleomagnetic data were plotted in order to identify the directions of characteristic remanent magnetization (ChRM) for each specimen employing the principal component analysis (PCA) with anchored line fit method (Kirschvink, 1980) using at least three or more data points presumably follow a linear segment of a trajectory. Mean directions for individual sites and formations were calculated using Fisher (1953) statistics. Specimens showing maximum angular deviation greater than $15^{\circ}$ and/or revealing directions quite different from the rest of the specimens within a site were not included for site mean calculation.

Isothermal remanent magnetization (IRM) acquisition experiments for selected samples were performed using an ASC Scientific Impulse Magnetizer (model IM-10). Hysteresis 
(a) Red Bed (E28-7) NRM M5 M10 M15 M20 M25 M30 M40 M50 M60 M70 M80 M90
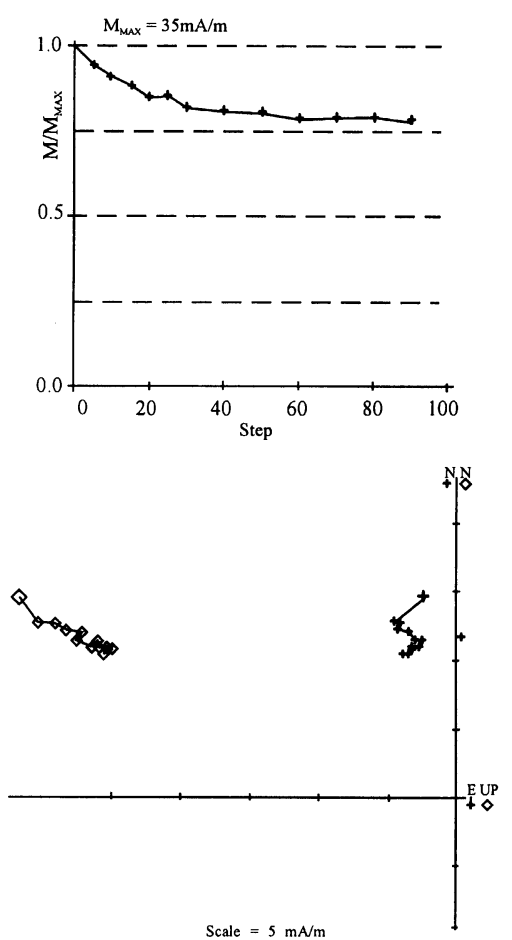

(c) Greenish Mudstone (E27-6) NRM M5 M10 M15 M20 M25 M30 M40 M50 M60 M70 M80 M90
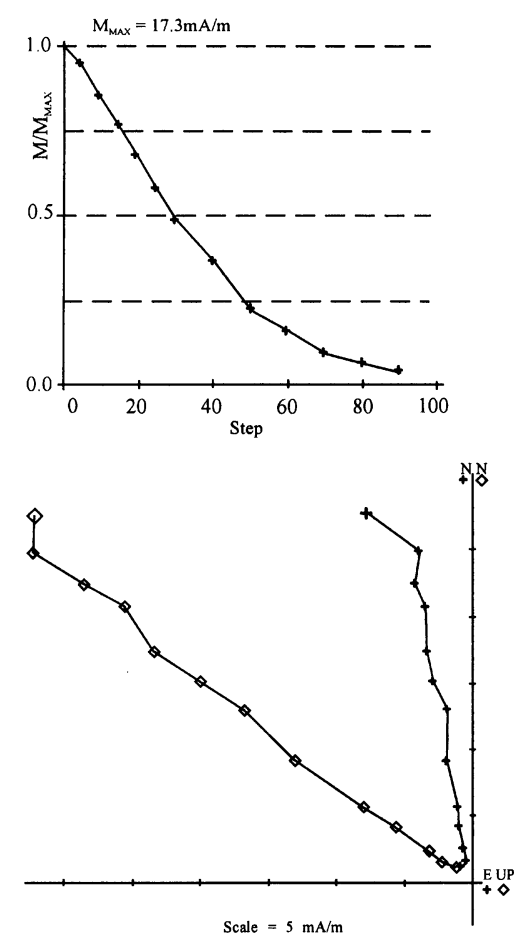

(b) Red Bed (E28-8)

NRM T100 T200 T300 T350 T400 T450 T500 T520 T540 T560 T580 T600 T620 T640 T660 T680
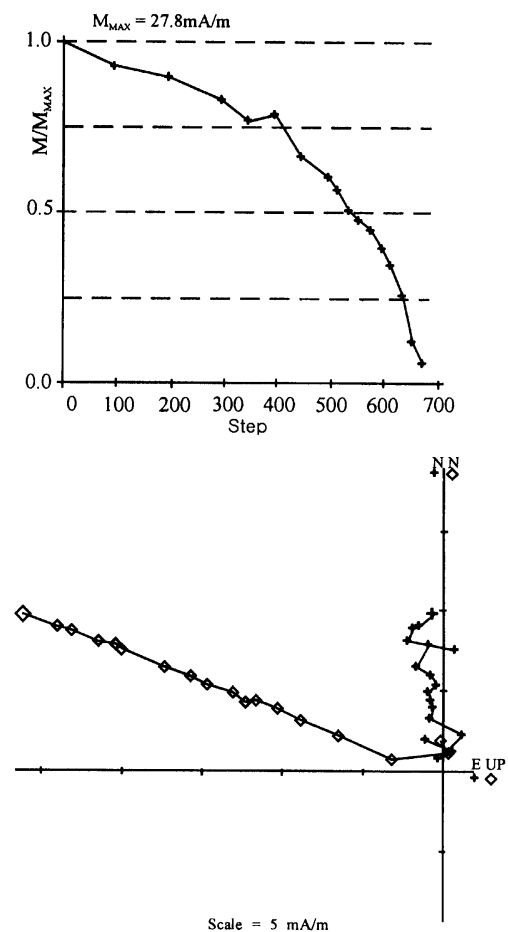

(d) Greenish Mudstone (E27-7) NRM T100 T200 T300 T350 T400 T450 T500 T520 T540 T560 T580 T600
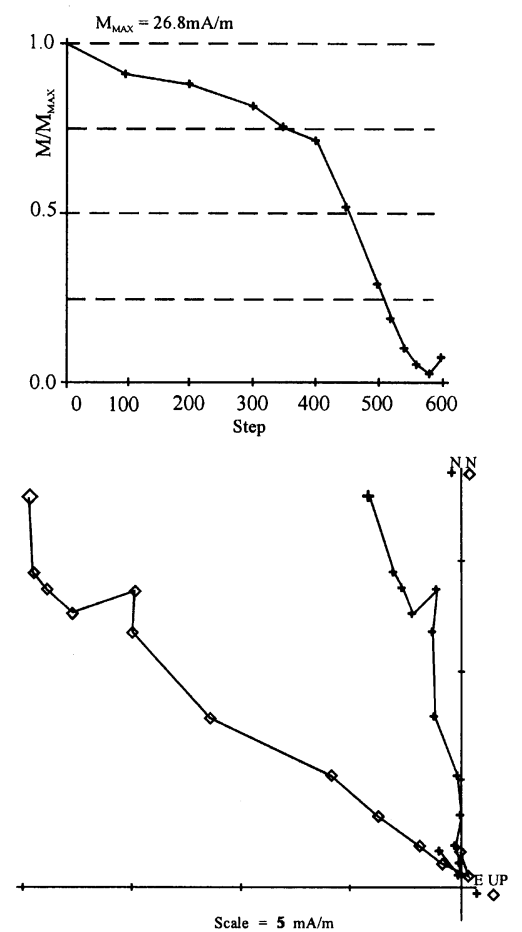

Fig. 2. Typical AF demagnetization ((a), (c)) and thermal demagnetization ((b), (d)) results of the samples from red bed ((a), (b)) and greenish mudstone ((c), (d)) of the Chopyeong Formation: normalized intensity curve and Zijderveld diagram in geographic coordinates. Demagnetization steps are shown below the sample number. 
Table 1. Paleomagnetic results from the Chopyeong Formation in the Eumsung basin.

\begin{tabular}{|c|c|c|c|c|c|c|c|c|c|c|c|c|c|c|}
\hline \multirow[b]{2}{*}{ Lithology } & \multirow[b]{2}{*}{ Site } & \multirow[b]{2}{*}{$n / N$} & \multicolumn{2}{|c|}{ SITE } & \multirow[b]{2}{*}{$D_{\mathrm{g}}$} & \multirow[b]{2}{*}{$I_{\mathrm{g}}$} & \multirow[b]{2}{*}{$D_{\mathrm{s}}$} & \multirow[b]{2}{*}{$I_{\mathrm{s}}$} & \multirow[b]{2}{*}{$k$} & \multirow[b]{2}{*}{$\alpha_{95}$} & \multicolumn{2}{|c|}{ VGP } & \multirow[b]{2}{*}{$d_{\mathrm{p}}$} & \multirow[b]{2}{*}{$d_{\mathrm{m}}$} \\
\hline & & & Long. & Lat. & & & & & & & Long. & Lat. & & \\
\hline & E2 & $9 / 10$ & 127.52 & 36.81 & 351.9 & 61.6 & 357.5 & 32.3 & 263.0 & 3.2 & 83.8 & 81.4 & 3.8 & 4.9 \\
\hline \multirow[t]{33}{*}{ Red bed } & E5 & $16 / 17$ & 127.51 & 36.84 & 317.5 & 61.2 & 16.5 & 56.5 & 253.6 & 2.3 & 60.4 & 57.1 & 2.7 & 3.5 \\
\hline & E6 & $9 / 12$ & 127.51 & 36.84 & 328.3 & 59.7 & 29.4 & 56.9 & 344.0 & 2.8 & 55.9 & 65.1 & 3.2 & 4.2 \\
\hline & E7 & $16 / 17$ & 127.58 & 36.85 & 326.9 & 54.6 & 354.2 & 59.6 & 243.4 & 2.4 & 43.9 & 63.3 & 2.4 & 3.4 \\
\hline & E8 & $24 / 25$ & 127.58 & 36.85 & 334.2 & 56.3 & 17.4 & 66.8 & 209.0 & 2.1 & 45.4 & 69.4 & 2.2 & 3.0 \\
\hline & E9 & $17 / 19$ & 127.58 & 36.85 & 333.4 & 58.6 & 47.0 & 64.9 & 217.7 & 2.4 & 52.5 & 69.0 & 2.6 & 3.6 \\
\hline & E10 & $55 / 55$ & 127.58 & 36.85 & 341.6 & 56.0 & 13.3 & 64.7 & 43.7 & 2.9 & 41.9 & 75.3 & 3.0 & 4.2 \\
\hline & E11 & $21 / 21$ & 127.56 & 36.85 & 343.6 & 55.4 & 359.1 & 47.8 & 281.3 & 1.9 & 38.5 & 76.8 & 1.9 & 2.7 \\
\hline & E12 & $18 / 18$ & 127.56 & 36.86 & 342.6 & 57.3 & 7.1 & 59.8 & 162.3 & 2.7 & 47.2 & 76.2 & 2.9 & 3.9 \\
\hline & E13 & $16 / 16$ & 127.56 & 36.85 & 343.5 & 53.0 & 347.3 & 61.7 & 416.9 & 1.8 & 28.7 & 76.1 & 1.7 & 2.5 \\
\hline & E14 & $19 / 19$ & 127.56 & 36.85 & 345.0 & 52.4 & 6.3 & 60.4 & 213.7 & 2.3 & 24.6 & 77.1 & 2.2 & 3.2 \\
\hline & E15 & $27 / 27$ & 127.56 & 36.86 & 347.5 & 53.7 & 6.3 & 61.3 & 92.0 & 2.9 & 26.8 & 79.5 & 2.8 & 4.0 \\
\hline & E16 & $20 / 20$ & 127.56 & 36.86 & 358.2 & 63.0 & 25.6 & 62.3 & 82.1 & 3.6 & 118 & 82.3 & 4.4 & 5.7 \\
\hline & E17 & $15 / 15$ & 127.56 & 36.86 & 327.9 & 56.4 & 358.9 & 60.7 & 378.2 & 2.0 & 47.6 & 64.5 & 2.1 & 2.9 \\
\hline & E18 & $14 / 14$ & 127.56 & 36.86 & 350.6 & 59.2 & 20.7 & 55.9 & 303.3 & 2.3 & 63.5 & 82.0 & 2.6 & 3.4 \\
\hline & E19 & $18 / 20$ & 127.56 & 36.87 & 0.8 & 53.5 & 321.0 & 56.5 & 71.8 & 4.1 & 294.3 & 87.1 & 4.0 & 5.7 \\
\hline & E20 & $29 / 29$ & 127.57 & 36.13 & 2.1 & 55.2 & 324.8 & 61.7 & 123.5 & 2.4 & 230.1 & 88.3 & 2.4 & 3.4 \\
\hline & E21 & $14 / 14$ & 127.57 & 36.87 & 358.9 & 50.6 & 349.9 & 58.3 & 107.5 & 3.9 & 317.2 & 84.4 & 3.5 & 5.2 \\
\hline & E23 & $19 / 19$ & 127.57 & 36.89 & 354.1 & 58.8 & 335.6 & 66.1 & 92.0 & 3.5 & 69.2 & 84.7 & 3.9 & 5.2 \\
\hline & E24 & $23 / 23$ & 127.57 & 36.88 & 354.7 & 54.6 & 18.2 & 56.7 & 158.4 & 2.4 & 16.9 & 85.4 & 2.4 & 3.4 \\
\hline & E28 & $16 / 17$ & 127.58 & 36.91 & 349.3 & 72.0 & 132.7 & 18.4 & 62.5 & 4.7 & 111.4 & 68.7 & 7.3 & 8.3 \\
\hline & E29 & $10 / 10$ & 127.58 & 36.9 & 346.5 & 55.0 & 337.5 & 73.6 & 280.7 & 2.9 & 34.4 & 79.0 & 2.9 & 4.1 \\
\hline & E30 & $22 / 22$ & 127.58 & 36.9 & 352.9 & 52.6 & 329.7 & 60.0 & 157.2 & 2.5 & 7.1 & 83.1 & 2.4 & 3.4 \\
\hline & E31 & $18 / 18$ & 127.58 & 36.9 & 353.9 & 54.0 & 36.8 & 68.9 & 300.1 & 2.0 & 13.9 & 84.5 & 2.0 & 2.8 \\
\hline & E32 & $19 / 19$ & 127.58 & 36.9 & 349.9 & 54.2 & 345.9 & 66.1 & 223.9 & 2.2 & 25.8 & 81.5 & 2.2 & 3.1 \\
\hline & E33 & $23 / 23$ & 127.58 & 36.9 & 353.2 & 56.9 & 265.8 & 73.2 & 208.7 & 2.1 & 45.8 & 84.6 & 2.2 & 3.1 \\
\hline & E34 & $18 / 18$ & 127.58 & 36.91 & 343.8 & 52.8 & 66.4 & 75.3 & 100.9 & 3.5 & 27.4 & 76.3 & 3.3 & 4.8 \\
\hline & E37 & $22 / 22$ & 127.59 & 36.89 & 351.4 & 50.7 & 348.1 & 59.3 & 363.0 & 1.6 & 2.5 & 81.0 & 1.5 & 2.2 \\
\hline & E38 & $24 / 24$ & 127.59 & 36.89 & 355.2 & 51.4 & 321.0 & 65.2 & 207.4 & 2.1 & 348.3 & 83.8 & 1.9 & 2.9 \\
\hline & E39 & $23 / 23$ & 127.59 & 36.89 & 354.0 & 59.6 & 43.2 & 53.8 & 268.1 & 1.9 & 76.6 & 84.1 & 2.1 & 2.9 \\
\hline & E40 & $20 / 20$ & 127.58 & 36.88 & 356.5 & 56.8 & 32.5 & 50.8 & 268.8 & 2.0 & 48.8 & 87.2 & 2.1 & 2.9 \\
\hline & Mean & 31 & & & 347.0 & 56.8 & & & 121.6 & 2.4 & 45.9 & 79.6 & $K$ & 66.3 \\
\hline & & & & & & & 1.0 & 62.2 & 21.4 & 5.7 & & & $A_{95}$ & $=3.2$ \\
\hline & E1 & $20 / 21$ & 127.52 & 36.79 & 322.4 & 77.7 & 336.8 & 24.3 & 46.3 & 4.8 & 103.4 & 53.4 & 8.4 & 9.0 \\
\hline \multirow{6}{*}{$\begin{array}{l}\text { Greenish } \\
\text { mudstone }\end{array}$} & E3 & $10 / 11$ & 127.52 & 36.81 & 3.5 & 61.4 & 11.5 & 57.5 & 292.4 & 2.8 & 151.7 & 83.7 & 3.3 & 4.3 \\
\hline & E4 & $15 / 16$ & 127.52 & 36.84 & 340.9 & 62.5 & 27.4 & 56.8 & 123.2 & 3.5 & 69.2 & 73.9 & 4.3 & 5.5 \\
\hline & E22 & $14 / 19$ & 127.56 & 36.9 & 358.9 & 50.6 & 349.9 & 58.3 & 107.5 & 3.9 & 116 & 72.5 & 2.5 & 2.9 \\
\hline & E27 & $21 / 21$ & 127.57 & 36.92 & 359.4 & 47.1 & 41.8 & 85.9 & 267.3 & 1.9 & 311.1 & 81.3 & 1.6 & 2.5 \\
\hline & Mean & 5 & & & 353.5 & 60.4 & & & 34.8 & 13.1 & 99.1 & 77.3 & $K$ & 22.0 \\
\hline & & & & & & & 358.9 & 58.4 & 10.7 & 24.6 & & & $A_{95}$ & 16.7 \\
\hline \multirow[t]{2}{*}{ Mean } & & $36 / 36$ & & & 347.8 & 57.3 & & & 92.8 & 2.5 & 53.7 & 79.8 & & 49.7 \\
\hline & & & & & & & 0.7 & 61.7 & 19.6 & 5.5 & & & & $=3.4$ \\
\hline
\end{tabular}

$n / N$ : number of samples used in average/measured; $D_{\mathrm{g}}$ and $I_{\mathrm{g}}$ : declination and inclination in geographic coordinates; $D_{\mathrm{s}}$ and $I_{\mathrm{s}}$ : declination and inclination in stratigraphic coordinates; $k$ : Fisherian precision parameter; $\alpha_{95}$ : radius of cone of $95 \%$ confidence interval; VGP: virtual geomagnetic pole; $d_{\mathrm{p}}$ : the semi axis of the confidence ellipse along the great-circle path from site to pole; $d_{\mathrm{m}}$ : the semi axis of the confidence ellipse perpendicular to that great-circle path; $K$ : the best-estimate of the precision parameter $k$ for the observed distribution of site-mean VGPs; $A_{95}$ : the radius of the $95 \%$ confidence circle about the calculated mean pole. 
(a) Western Granite (E35-5) NRM M5 M10 M15 M20 M25 M30 M40 M50 M60 M70 M80 M90
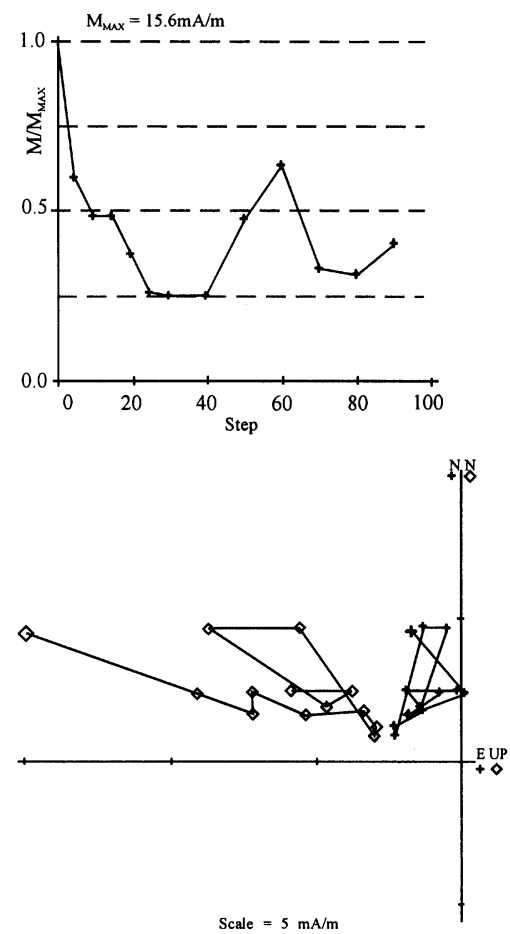

(b) Eastern Granite (E44-2) NRM M5 M10 M15 M20 M25 M30 M40 M50 M60 M70 M80 M90
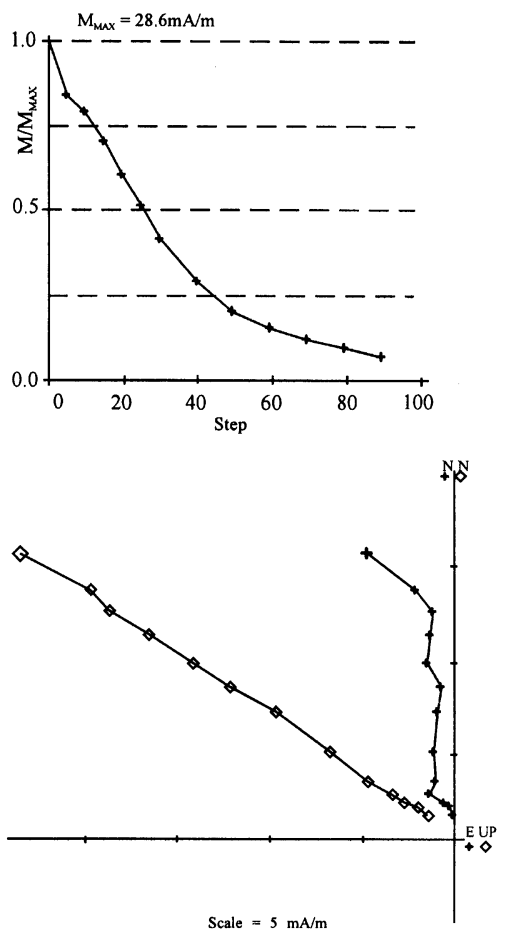

Fig. 3. Typical AF demagnetization results of the samples from (a) granite in the west to the basin showing abrupt directional changes and (b) granite in the east to the basin revealing gradual decrease toward the origin: normalized intensity curve and Zijderveld diagram in geographic coordinates. Demagnetization steps are shown below the sample number.

Table 2. Paleomagnetic results from the granites in the Eumsung basin.

\begin{tabular}{|c|c|c|c|c|c|c|c|c|c|c|c|c|}
\hline \multirow[b]{2}{*}{ Lithology } & \multirow[b]{2}{*}{ Site } & \multirow[b]{2}{*}{$n / N$} & \multicolumn{2}{|c|}{ SITE } & \multirow[b]{2}{*}{$D_{\mathrm{g}}$} & \multirow[b]{2}{*}{$I_{\mathrm{g}}$} & \multirow[b]{2}{*}{$k$} & \multirow[b]{2}{*}{$\alpha_{95}$} & \multicolumn{2}{|c|}{ VGP } & \multirow[b]{2}{*}{$d_{\mathrm{p}}$} & \multirow[b]{2}{*}{$d_{\mathrm{m}}$} \\
\hline & & & Long. & Lat. & & & & & Long. & Lat. & & \\
\hline \multirow{3}{*}{$\begin{array}{l}\text { Western } \\
\text { granite }\end{array}$} & E35 & $17 / 17$ & 127.58 & 36.95 & 325.5 & 63.1 & 8.3 & 13.2 & 64.9 & 63.0 & 16.4 & 20.8 \\
\hline & E41 & $15 / 15$ & 127.59 & 36.98 & 16.4 & 52.8 & 22.8 & 7.9 & 76.1 & 228 & 7.2 & 10.5 \\
\hline & Mean & $32 / 32^{*}$ & & & $354.6^{*}$ & $59.9^{*}$ & 9.1 & 8.8 & 74.1 & 82.9 & \multicolumn{2}{|c|}{$\begin{array}{c}K=8.3 \\
A_{95}=103.0\end{array}$} \\
\hline \multirow{5}{*}{$\begin{array}{l}\text { Eastern } \\
\text { granite }\end{array}$} & E36 & $12 / 15$ & 127.62 & 36.91 & 333.7 & 43.0 & 85.6 & 4.7 & 17.1 & 64.6 & 3.6 & 5.8 \\
\hline & E43 & $12 / 12$ & 127.64 & 36.86 & 2.9 & 44.2 & 55.0 & 5.9 & 294.1 & 78.8 & 4.6 & 7.4 \\
\hline & E44 & $14 / 14$ & 127.61 & 36.79 & 349.1 & 54.2 & 476.3 & 1.8 & 27.7 & 80.9 & 1.8 & 2.5 \\
\hline & Mean & $38 / 41^{*}$ & & & $347.0^{*}$ & $47.0^{*}$ & 40.2 & 3.6 & 33.3 & 77.6 & \multicolumn{2}{|c|}{$\begin{array}{c}K=33.3 \\
A_{95}=21.7\end{array}$} \\
\hline & Mean & 5 & & & 350.5 & 52.8 & 29.9 & 14.2 & 21.1 & 81.5 & \multicolumn{2}{|c|}{$\begin{array}{c}K=18.7 \\
A_{95}=18.2\end{array}$} \\
\hline
\end{tabular}

$n / N$ : number of samples used in average/measured; $D_{\mathrm{g}}$ and $I_{\mathrm{g}}$ : declination and inclination in geographic coordinates; $k$ : Fisherian precision parameter; $\alpha_{95}$ : radius of cone of $95 \%$ confidence interval; VGP: virtual geomagnetic pole; $d_{\mathrm{p}}$ : the semi axis of the confidence ellipse along the great-circle path from site to pole; $d_{\mathrm{m}}$ : the semi axis of the confidence ellipse perpendicular to that great-circle path; $K$ : the best-estimate of the precision parameter $k$ for the observed distribution of site-mean VGPs; $A_{95}$ : the radius of the $95 \%$ confidence circle about the calculated mean pole; Western granite: granite in the western area of the basin; Eastern granite: granite in the eastern area of the basin; * mean directions calculated as if all specimens were of the same sites for Western and Eastern granites.

parameters were measured with a vibrating sample magnetometer (Molspin Ltd., model VSM Nuvo). Electron microscope observations were carried out to confirm the charac- teristic size, shape, paragenesis, and composition of magnetic carriers. 


\section{Paleomagnetic Results}

\subsection{Chopyeong Formation}

Among the total of 36 sites from the Chopyeong Formation, 31 sites are from red bed and 5 sites are from the greenish mudstone facies. The number of sites in greenish mudstone is much less because available outcrops are very limited in the area.

The natural remanent magnetization (NRM) directions of the Chopyeong Formation are predominantly northerly positive, clustering more closely about the present-field direction $\left(D / I=352.6^{\circ} / 52.9^{\circ}\right)$ than the mean axial dipole field $\left(D / I=0^{\circ} / 56.3^{\circ}\right)$, suggesting that the NRMs are merely dominated by components of viscous origin.

From demagnetization of pilot samples of red bed, thermal demagnetization is turned out to be the most effective method to isolate the characteristic component from the red bed because AF demagnetization even at the field strength of $90 \mathrm{mT}$ cannot remove the remanent magnetization successfully (Fig. 2(a)). The low temperature component, a viscous remanent magnetization (VRM) component, can be removed in the initial demagnetization stage of temperature at or below $300^{\circ} \mathrm{C}$. Above $300^{\circ} \mathrm{C}$, a converging component appears up to $620-640^{\circ} \mathrm{C}$ heating steps, and then the direction starts to randomize with the increase of susceptibility but the magnetic intensity decreases continuously until $680^{\circ} \mathrm{C}$ (Fig. 2(b)). The ChRM was isolated mainly from $300^{\circ} \mathrm{C}$ to $640^{\circ} \mathrm{C}$. The mean direction of the ChRMs from the red bed is $D / I=347.0^{\circ} / 56.8^{\circ}\left(k=121.6, \alpha_{95}=2.4^{\circ}\right)$ before tilt correction and $D / I=1.0^{\circ} / 62.2^{\circ}\left(k=21.4, \alpha_{95}=5.7^{\circ}\right)$ after tilt correction. The site-mean direction of red bed is more dispersed after tilt correction.

Both $\mathrm{AF}$ and thermal demagnetization methods are effective to isolate ChRM direction for the greenish mudstone (Figs. 2(c) and (d)). For the ChRMs isolated using an AF demagnetization method, the low coercivity component is removed below $15 \mathrm{mT}$ and then the characteristic component is isolated above $20 \mathrm{mT}$. The mean direction of the greenish mudstone is $D / I=353.5^{\circ} / 60.4^{\circ}\left(k=34.8, \alpha_{95}=13.1\right)$ before tilt correction and $D / I=358.9^{\circ} / 58.4^{\circ}(k=10.7$, $\left.\alpha_{95}=24.6^{\circ}\right)$ after tilt correction. Tilt corrected directions are more dispersed than in-situ directions, indicating greenish mudstone acquired the remanence after tilting of the strata. The mean direction of the Chopyeong Formation including red and greenish beds is $D / I=347.8^{\circ} / 57.3^{\circ}(k=92.8$, $\left.\alpha_{95}=2.5^{\circ}\right)$ before tilt correction and $D / I=0.7^{\circ} / 61.7^{\circ}$ $\left(k=19.6, \alpha_{95}=5.5^{\circ}\right)$ after tilt correction (Table 1).

\subsection{Granite}

Granites show two different demagnetization behaviors. Because samples from the western part of the study area generally show unstable remanent directions and abrupt changes in intensity (Fig. 3(a)), it is difficult to isolate the ChRMs. In contrast, samples from the eastern part show stable remanent directions and gradual decrease of intensity (Fig. 3(b)). In the samples from the western granite, the characteristic components are determined at $5-15 \mathrm{mT}$, whereas the ChRMs for the eastern granite are isolated at 20-60 mT. The paleomagnetic mean direction of the two granite bodies is $D / I=350.5^{\circ} / 52.8^{\circ}\left(k=29.9, \alpha_{95}=14.2^{\circ}\right)$ (Table 2$)$. The paleomagnetic directions representing the granites in the east and in the west are, however, separately recalcu- lated as if they were site-mean directions for the east and west granites because of the statistically meaningless number of sites for each granite. The mean direction, calculated in this way, of the east granite is $D / I=347.0^{\circ} / 47.7^{\circ}$ $\left(k=40.2, \alpha_{95}=3.6^{\circ}\right)$ and that of the west granite is $D / I=354.6^{\circ} / 59.5^{\circ}\left(k=9.1, \alpha_{95}=8.8^{\circ}\right)$.

\section{Rock Magnetic Results}

\subsection{IRM acquisition experiment}

IRM acquisition experiment is employed to distinguish magnetic carriers whether they are members of magnetiteulvöspinel series or hematite-ilmenite series. Magnetite is usually saturated in field of $<150 \mathrm{mT}$, while the field required to saturate hematite ranges from $200 \mathrm{mT}$ for coarse specular hematite to 2 Tesla or more for fine pigmentary hematite (Piper, 1987).

The samples of this study can be grouped on the basis of the behavior of IRM acquisition. First, all samples from greenish mudstone of the Chopyeong Formation and granite in the east to the basin, and samples from site 41 of the west granite show steeply inclining IRM intensity to a field of 100 $\mathrm{mT}$ and about $90 \%$ saturation is achieved at $200 \mathrm{mT}$ (Fig. 4). This behavior suggests that ferrimagnetic material makes an

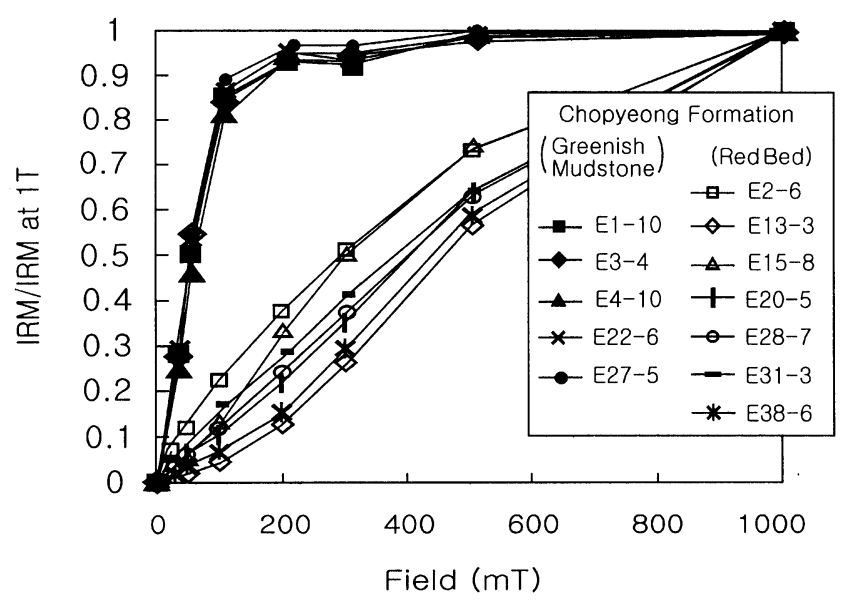

(a)

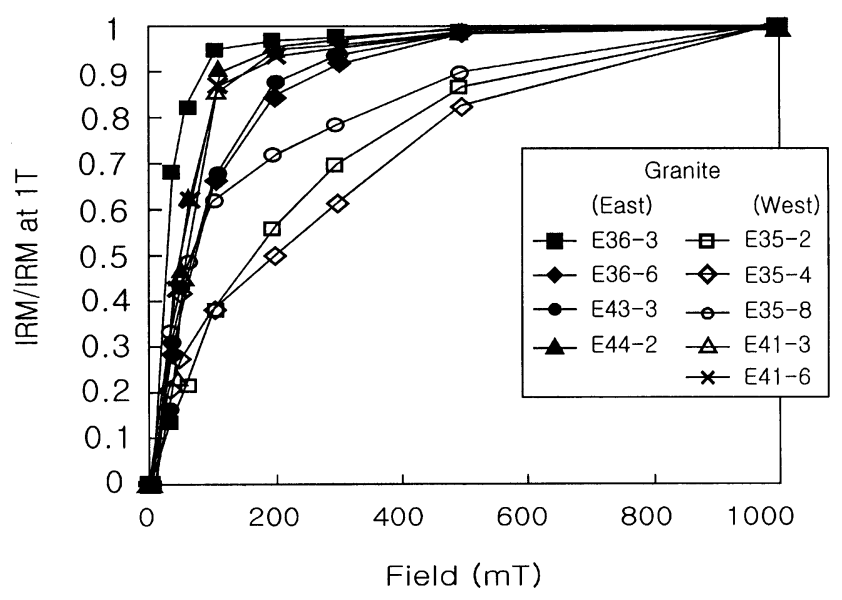

(b)

Fig. 4. IRM acquisition curves for the samples (a) from the Chopyeong Formation and (b) from the granite. 


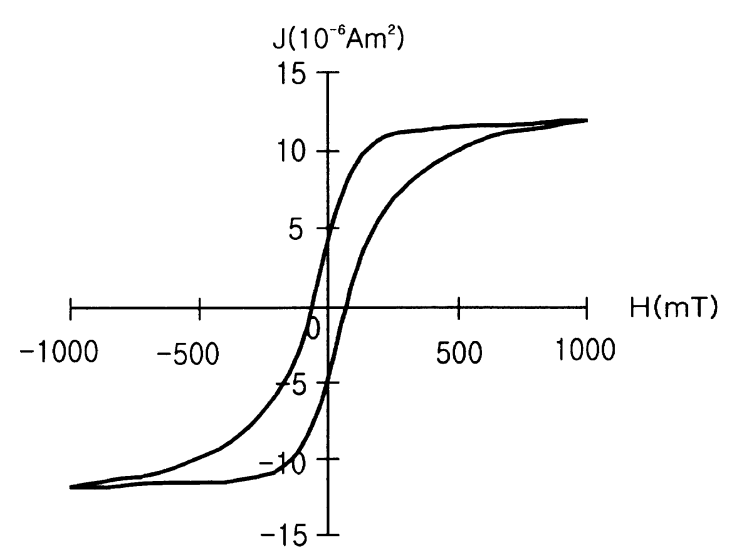

(a)

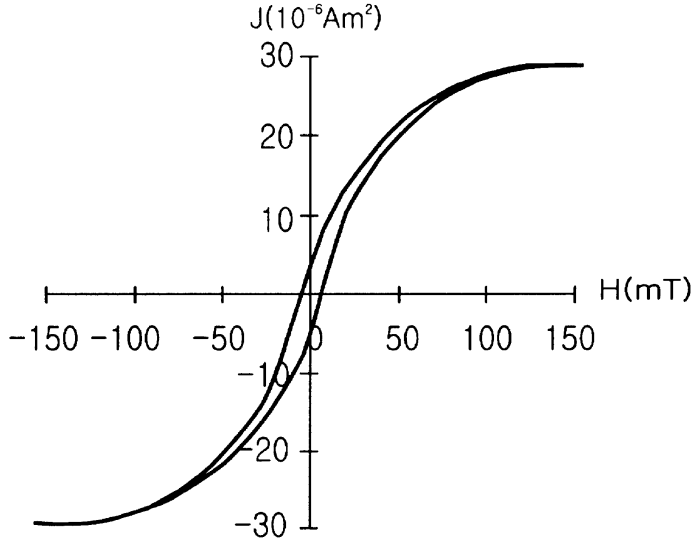

(b)

Fig. 5. Typical hysteresis loops from (a) red bed and (b) greenish mudstone of the Chopyeong Formation.

Table 3. Hysteresis parameters of selected samples.

\begin{tabular}{cccrcc}
\hline No. & $M_{\mathrm{s}}\left(\mu \mathrm{Am}^{2}\right)$ & $M_{\mathrm{rs}}\left(\mu \mathrm{Am}^{2}\right)$ & $H_{\mathrm{c}}(\mathrm{mT})$ & $H_{\mathrm{cr}}(\mathrm{mT})$ & Rock type \\
\hline E2-6 & 3.5 & 1.9 & 83.6 & 311.8 & Red bed \\
E13-3 & 6.8 & 5.1 & 321.9 & 474.2 & \\
E15-8 & 70.1 & 4.7 & 67.8 & 310.2 & \\
E20-5 & 5.6 & 3.4 & 137.2 & 409.6 & \\
E38-3 & 38.6 & 3.4 & 327.7 & 460.9 & \\
\hline E1-10 & 3.1 & 1.2 & 14.5 & 44.3 & Greenish mudstone \\
E4-10 & 1.6 & 0.6 & 14.9 & 44.5 & \\
E22-6 & 1.6 & 0.7 & 13.9 & 43.0 & \\
E27-5 & 2.9 & 1.2 & 14.6 & 40.8 & \\
\hline E36-3 & 27.5 & 3.6 & 4.9 & 13.8 & Granite \\
E36-6 & 4.4 & 0.3 & 7.5 & 41.6 & \\
E41-6 & 4.4 & 1.2 & 16.2 & 41.9 & \\
E44-2 & 7.5 & 2.0 & 10.2 & 25.7 & \\
\hline
\end{tabular}

$M_{\mathrm{s}}$ : Saturation Magnetization; $M_{\mathrm{rs}}$ : Saturation Remanence; $H_{\mathrm{c}}$ : Coercive Force; $H_{\mathrm{cr}}$ : Coercivity of Remanence.

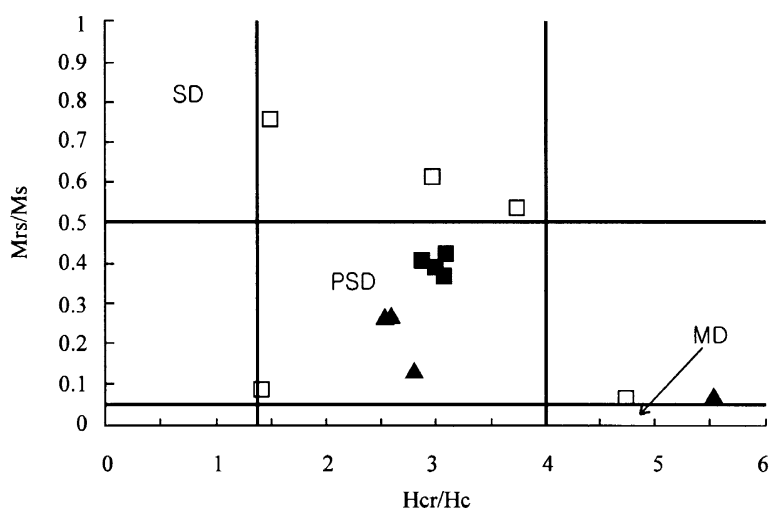

Fig. 6. Hysteresis properties and domain state for the selected samples. Open square: red bed; solid square: greenish mudstone; solid triangle: granite (after Day et al., 1977). important contribution to the IRM acquisition and the amount of canted antiferromagnetic material is minor. It is also observed in the thermal demagnetization experiments that the remanent magnetization is unblocked mainly at $560-580^{\circ} \mathrm{C}$ (Fig. 2(d)). Secondly, samples from granite in the west collected at site 35 show about $90 \%$ saturation at $500 \mathrm{mT}$ and then gradual increase of the IRM intensity in the field above the $500 \mathrm{mT}$ (Fig. 4(b)), suggesting that ferrimagnetic material and canted antiferromagnetic materials contribute equally to the IRM acquisition. The third group, all samples from red bed of the Chopyeong Formation shows continuous increase in IRM intensity with increasing field (Fig. 4(a)), indicating canted antiferromagnetic material makes an important contribution to the IRM acquisition and the amount of ferrimagnetic mineral is negligible. The thermal demagnetization behavior also revealed that the remanent magnetization is unblocked mainly in the range of $660-680^{\circ} \mathrm{C}$ (Fig. 2(b)). 


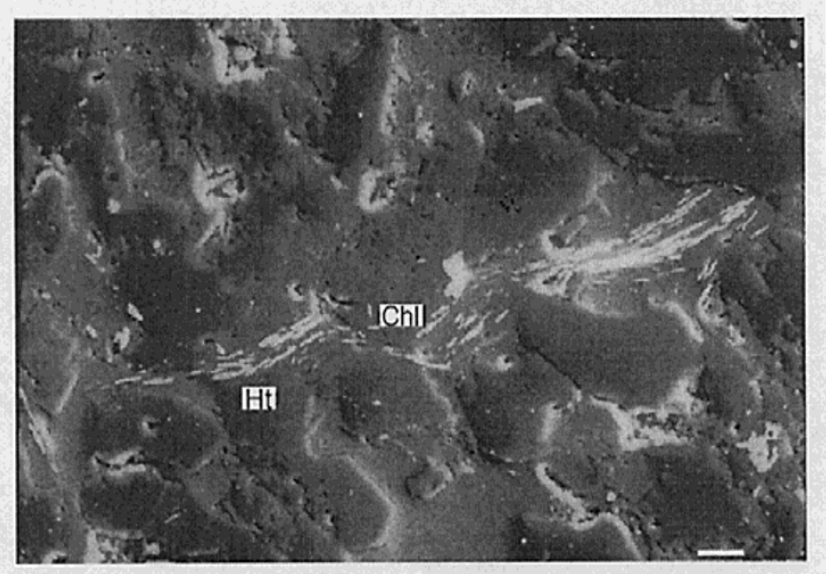

$10 \mu \mathrm{m}$

(a)

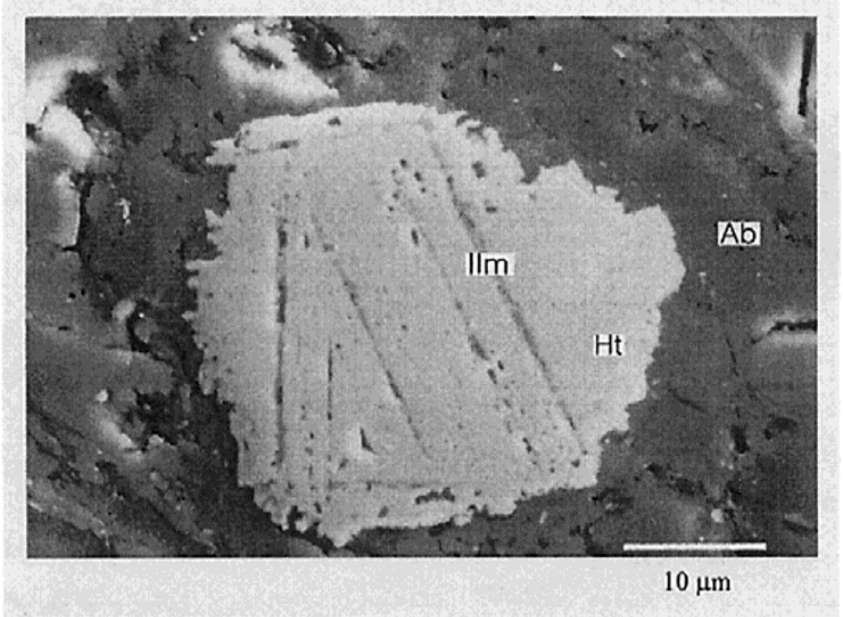

(b)

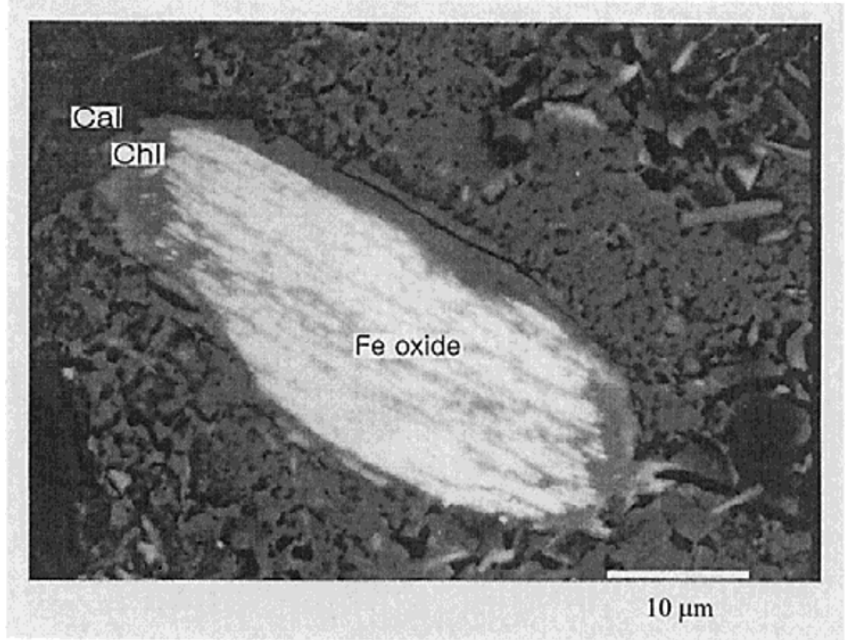

(c)

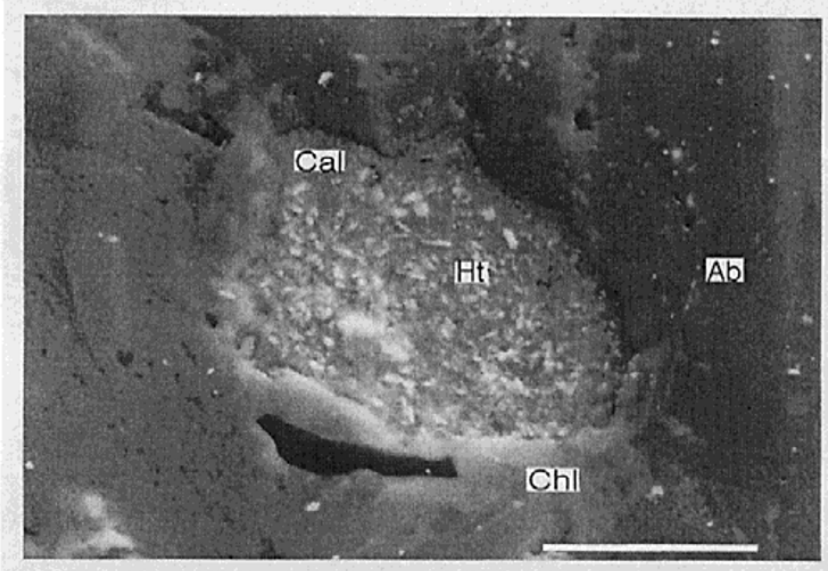

$10 \mu \mathrm{m}$

(d)

Fig. 7. Secondary electron image of the samples from red bed ((a), (b)) and greenish mudstone ((c), (d)) of the Chopyeong Formation showing hematite and magnetite. (a) Hematite (Ht) formed along the cleavages of chlorite (Chl). (b) Detrital hematite adjacent to albite (Ab) with ilmenite (Ilm) lamella. (c) Submicron sized iron oxides also formed along the cleavages of chlorite (Chl). (d) Hematite (Ht, white needle shaped grains) within the calcite matrix (Cal, light grey).

\subsection{Hysteresis parameters}

Hysteresis parameters are measured from the representative samples of red bed and greenish mudstone. Small cylindrical samples of $7 \mathrm{~mm}$ in diameter and $10 \mathrm{~mm}$ in height were prepared for hysteresis measurements. Hysteresis loops were obtained on a Molspin Nuvo vibrating sample magnetometer. Saturation magnetization $\left(M_{\mathrm{s}}\right)$, saturation remanence $\left(M_{\mathrm{rs}}\right)$, and coercive force $\left(H_{\mathrm{c}}\right)$ were determined after corrections of the magnetic moment for high field paramagnetic and diamagnetic slope. Remanent coercivity $\left(H_{\mathrm{cr}}\right)$ was obtained from stepwise back field demagnetization of samples given IRM. Hysteresis loops from red bed show typical results of hematite (Fig. 5(a)) and those of greenish mudstone display typical results of magnetite (Fig. 5(b)).

Hysteresis parameters, such as $M_{\mathrm{s}}, M_{\mathrm{rs}}, H_{\mathrm{c}}$, and $H_{\mathrm{cr}}$, of samples are listed in Table 3. The values of $H_{\mathrm{cr}}$ are commonly used to distinguish magnetic minerals in a way that minerals of the corundum structure, such as hematite, have $H_{\text {cr }}$ above $200 \mathrm{mT}$ while minerals of the spinel structure, such as magnetite, have $H_{\mathrm{cr}}$ below $50 \mathrm{mT}$ (Thompson et al., 1980). All samples of greenish mudstone and granite have $H_{\mathrm{cr}}$ less than $50 \mathrm{mT}$, while all samples of red bed show $H_{\mathrm{cr}}$ above $300 \mathrm{mT}$. The grouping on the basis of values of $H_{\mathrm{cr}}$ is well matched with the grouping based on the IRM acquisition experiments. The ratios of hysteresis parameters, $H_{\mathrm{cr}} / H_{\mathrm{c}}$ and $M_{\mathrm{rs}} / M_{\mathrm{s}}$, are used to diagnose the domain state of magnetic minerals (Day et al., 1977). All samples from greenish mudstone of the Chopyeong Formation belong to pseudo-single domain (PSD) region (Fig. 6). The samples from granite also reveal that they contain magnetic mineral in the range of PSD to multidomain (MD) regions. Although the plot of $M_{\mathrm{rs}} / M_{\mathrm{s}}$ against $H_{\mathrm{cr}} / H_{\mathrm{c}}$ is used to determine the domain state of magnetite-bearing samples, results from red bed are also shown in Fig. 6. 


\section{Electron Microscope Observations}

To characterize the shape, size, and paragenesis of magnetic carriers, electron microscope observations were carried out for representative samples from the Chopyeong Formation and granite. In order to identify iron oxide and adjacent grains or matrix of magnetic carriers, compositional analysis using energy dispersive spectroscopic (EDS) system for $\mathrm{X}$-ray analysis were performed.

In samples of the Chopyeong Formation, opaque grains of submicron to $3 \mu \mathrm{m}$ in size are abundant, and a few large irregular grains $(10-20 \mu \mathrm{m})$ are also found. As expected from demagnetization experiments, submicron-size needle shaped hematite grains infilling the cleavages of chlorite are the most frequently observed type of magnetic mineral from red bed of the Chopyeong Formation (Fig. 7(a)). Hematite grains shown in Fig. 7(a) suggest that they were formed either by precipitation from Fe-bearing fluids or replacement of preexisting phases (Walker et al., 1981). Large hematite grain of

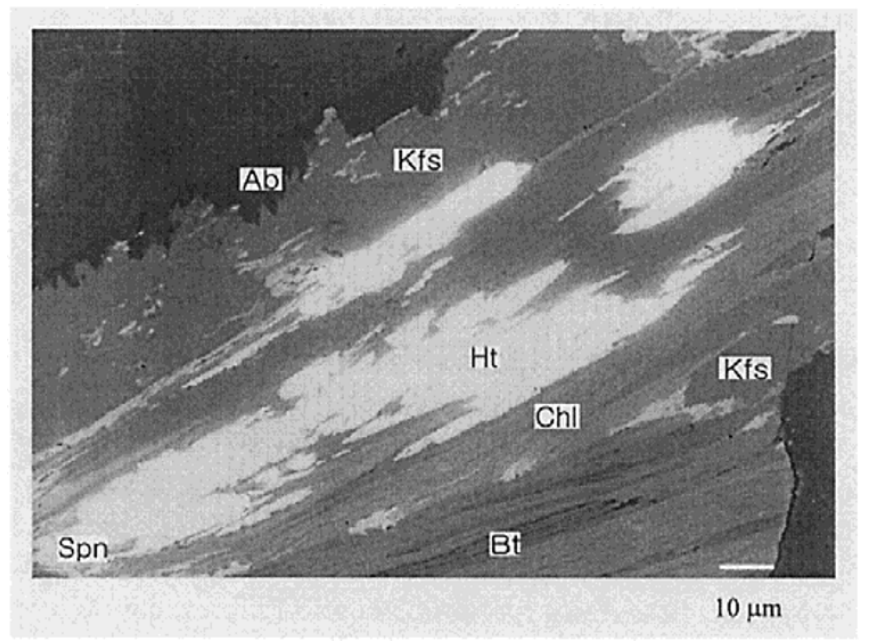

(a)

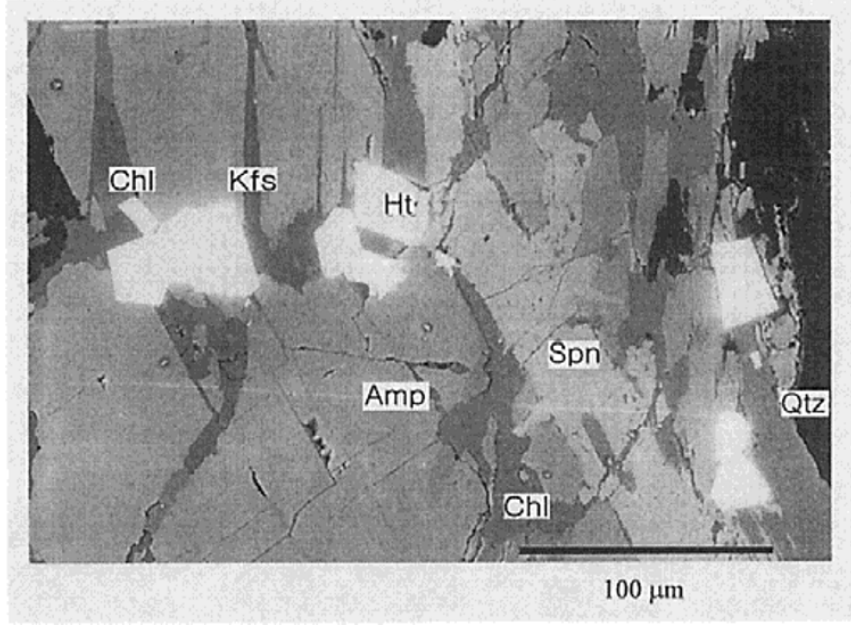

(b)

Fig. 8. Back-scattered electron image of the samples from (a) granite in the west to the basin and (b) granite in the east to the basin. Ht: hematite; Chl: chlorite; Bt: biotite; Ab: albite; Kfs: K-feldspar; Spn: sphene; Qtz: quartz; Amp: amphibole. about $30 \mu \mathrm{m}$ in size shows detrital features, ilmenite lamella (Fig. 7(b)). Detrital iron oxide grains were known to show severely corroded features and some relict phases such as titanomagnetite, titanohematite, or rutile (Suk et al., 1990). In addition, a few magnetite grains in the range of SD to PSD, that are believed to be formed authigenically, are also observed.

Although compositional analysis cannot distinguish whether the Fe oxides smaller than $1 \mu \mathrm{m}$ are precisely magnetite or hematite in the samples from greenish bed of the Chopyeong Formation, significant amounts of the small $\mathrm{Fe}$ oxide grains in the range of SD are inevitably assumed to be magnetite based on the demagnetization behavior. The typical grains of this kind is the submicron sized iron oxide grains are formed along the cleavages of chlorite (Fig. 7(c)). Hematite grains are observed as a minor constituent in the matrix of calcite (Fig. 7(d)).

From the granite in the west to the basin, elongated hematite grains up to $100 \mu \mathrm{m}$ in length, the most common type of magnetic mineral, are interpreted that they formed as a result of alteration along the cleavages of chlorite accompanied with biotite, albite, K-feldspar and sphene mineral assemblage associated with alteration of pre-existing minerals (Fig. 8(a)). These observations evidently indicate that the granite in the west underwent some degree of alteration after crystallization of magma. Unlike the electron microscope observations of the granite from the west, the granite in the east to the basin does not reveal any profound signs of alteration and/or dissolution-precipitation of pre-existing minerals. Although magnetite grains are not observed as they are expected from the rock magnetic results, Fig. 8(b) shows that hematite along with amphibole, K-feldspar, quartz, chlorite and sphene is primary in origin.

\section{Discussion}

\subsection{Remagnetization of the Chopyeong Formation}

The gently to moderately dipping $\left(10^{\circ}-40^{\circ}\right)$ Chopyeong Formation revealed more dispersed paleomagnetic mean direction after tilt correction (Fig. 9). In this case, it has long been termed as a negative fold test of McElhinny (1964) using $k_{2} / k_{1}$ ratio. McFadden and Jones (1981), however, pointed out that the fold test is not valid because it is not possible to test statistically whether the remanence is significantly more clustered after (or before) tilt correction. They proposed a new hypothesis test to check whether the data are incompatible before and after tectonic correction. More recently Watson and Enkin (1993) argued that the hypothesis test of McFadden and Jones (1981) has difficulties especially when the remanence is not simply pre- or post-tilting and they suggested that the fold test is rather considered as a parameter estimation problem to estimate the amount of tectonic tilting at the time of magnetization than a hypothesis test.

The parameter estimation fold test (Watson and Enkin, 1993) and stepwise unfolding test were performed for the data of the Chopyeong Formation. The parameter estimation fold test gives the maximum $k$ value for the Chopyeong Formation at $21.9 \%$ untilting, with $95 \%$ confidence interval of $2 \%$ untilting when the number of parametric resampling is 300. Separately computed stepwise unfolding test of the red bed and greenish mudstone also yielded maximum clustering 


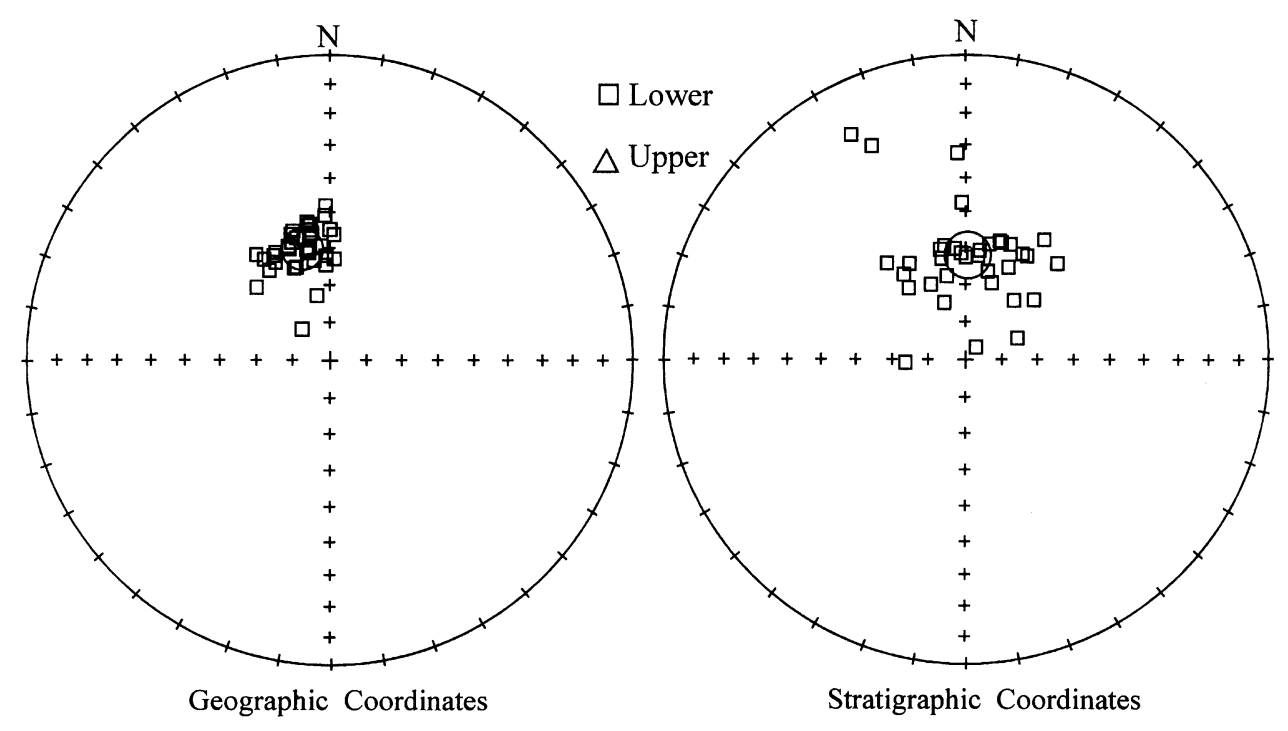

(a)

(b)

Fig. 9. Paleomagnetic mean directions of the Chopyeong Formation with $95 \%$ confidence circle and site mean directions of $\left(\right.$ a) before $\left(D / I=347.8^{\circ} / 57.3^{\circ}\right.$, $\left.k=92.8, \alpha_{95}=2.5^{\circ}\right)$ and (b) after $\left(D / I=0.7^{\circ} / 61.7^{\circ}, k=19.6, \alpha_{95}=5.5^{\circ}\right)$ tilt correction.

at $20 \%$ untilting (Fig. 10), which is in fairly good agreement with the results of the parameter estimation fold test. The paleomagnetic directions of the red bed and greenish bed at $20 \%$ untilting are $D / I=349.3^{\circ} / 58.2^{\circ}\left(k=205.7, \alpha_{95}=1.8^{\circ}\right)$ and $D / I=359.4^{\circ} / 55.9^{\circ}\left(k=144.1, \alpha_{95}=6.4^{\circ}\right)$, respectively. And the combined mean direction of the red and greenish beds of the Chopyeong Formation at 20\% untilting turns out to be $D / I=350.8^{\circ} / 57.9^{\circ}(k=177.9$, $\alpha_{95}=1.8^{\circ}$ ). Incomplete isolation of characteristic component, a common cause of a maximum $k$ value not being at $0 \%$ or $100 \%$, can be ruled out because the demagnetization results indicate successful isolation of ChRMs (Fig. 2). The stepwise unfolding test and the parameter estimation fold test, showing more tightly clustered mean direction at $20 \%$ untilting, clearly indicate that the ChRM of the Chopyeong Formation is not a primary component but a remagnetized one, although it is hard to determine whether the magnetization of the Chopyeong Formation was acquired during tilting or not. This is also supported by the fact that the characteristic direction is significantly different from the directions obtained from Cretaceous rocks in the Gyeongsang basin (Kim and Jeong, 1986; Lee et al., 1987; Doh et al., 1994).

The timing and processes of remagnetization provide important insights into the orogenic and geochemical process responsible for the remagnetization (Butler, 1992). There are several possible mechanisms proposed for remagnetization. Chemical remanent magnetization (CRM) acquired by the formation of authigenic magnetic minerals in association with the lateral migration of orogenic or basinal fluids, introduction of meteoric fluids, as well as migration of hydrocarbons has been proposed as the mechanism of remagnetization (McCabe et al., 1983; Oliver, 1986; Elmore and McCabe, 1991). Prolonged exposure to elevated temperature below the Curie temperature affecting the ability of rocks to retain a primary NRM has been suggested responsible for the acquisition of thermoviscous magnetization (TVRM, e.g., Kent, 1985). Strain-related remagnetization (e.g., Hudson et $a l ., 1989)$ and surface weathering (e.g., Otofuji et al., 1989) also have been nominated to bring the remagnetization.

Strain-related remagnetization is the most unlike mechanism because the strata are gently tilted without severe deformation. Surface weathering should be ruled out because uniform polarity and the well clustered directions are hard to be acquired by weathering processes and more importantly hematite and magnetite observed by electron microscope observations cannot be produced at the same time by weathering processes. The intrusion of Cretaceous to Tertiary Bulguksa granite might cause TVRM. In order to acquire TVRM with an unblocking temperature of $640-660^{\circ} \mathrm{C}$ for hematite, it is needed to be heated above $550^{\circ} \mathrm{C}$ for, at least, $10 \mathrm{My}$ based on the blocking temperature-relaxation time curves of Pullaiah et al. (1975). Despite that such temperature condition should have resulted in considerable degree of contact metamorphism in rocks, the strata in the study area do not show any signs of the metamorphism due to high temperature. Thus, remagnetization by TVRM can be denied. The electron microscope observations strongly suggest that the magnetic carriers, hematite and magnetite, are secondary products formed under the influence of fluids (Figs. 7 and 8). Therefore, chemical remagnetization is turned out to be the major process that causes the acquisition of secondary magnetization.

The paleomagnetic pole calculated from the untilted characteristic direction of the Chopyeong Formation is at $53.7^{\circ} \mathrm{E}$, $79.8^{\circ} \mathrm{N}\left(K=49.7, A_{95}=3.4^{\circ}\right)$. This paleomagnetic pole is close to the Tertiary pole when it is compared with the paleomagnetic poles of early Cretaceous to Quaternary in Korea (Fig. 11(a)). Because the sedimentary rocks of 


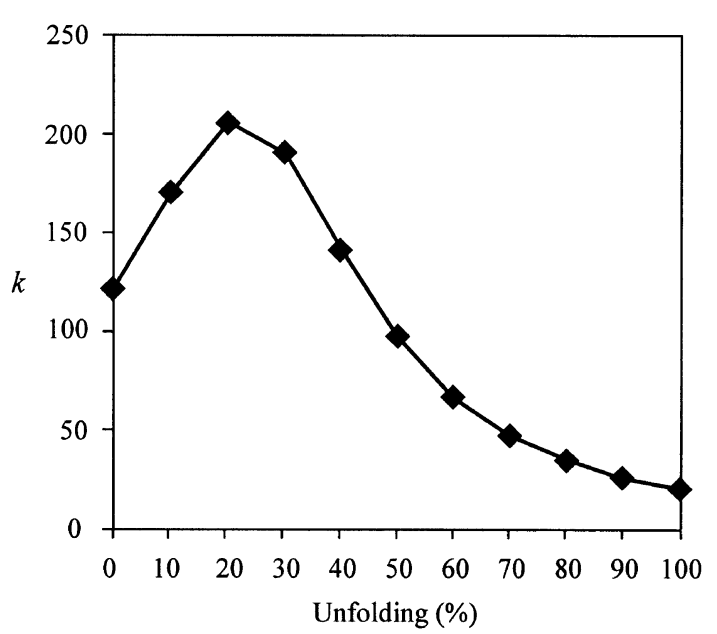

(a)

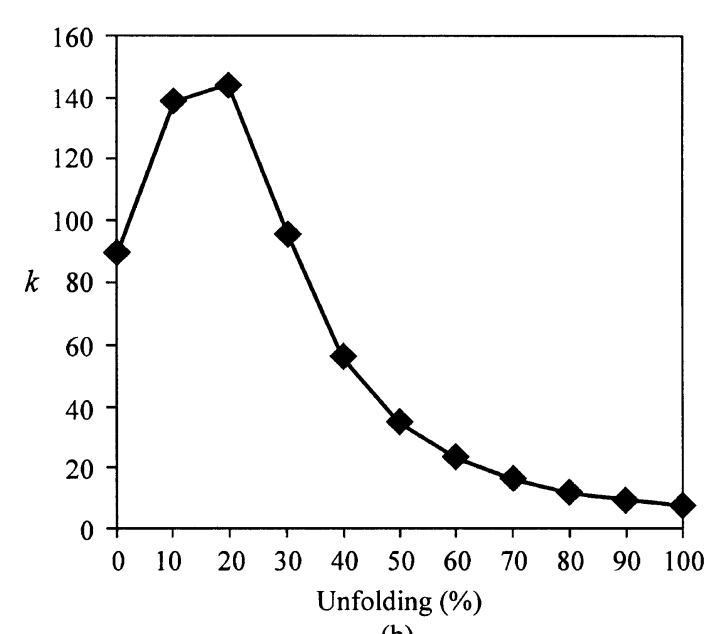

(b)

Fig. 10. Syntilting test plotting Fisher's precision parameter $(k)$ versus percent untilting. (a) red bed and (b) greenish mudstone.

the Chopyeong Formation bearing charophyta are dated as uppermost Hauterivian-Aptian, the remagnetization should have occurred after Aptian. The most probable event responsible for the remagnetization is the volcanism and the intrusion of Bulguksa granite in late Cretaceous and early Tertiary because any remarkable disturbances that would cause the remagnetization have not occurred after Tertiary. The paleomagnetic poles of the Chopyeong Formation from this study, late Cretaceous volcanic rocks in the Youngdong basin and the Yucheon Group in the Euisung area of the Gyeongsang basin are compared (Fig. 11(b)). The fact that the paleomagnetic pole of the Chopyeong Formation is statistically indistinguishable from those of late Cretaceous volcanic rocks confirms not only that the remanence of the Chopyeong Formation was acquired during late Cretaceous and early Tertiary at the time of the igneous activities but also that the possible rotation of the study area due to the formation of the sinistral faults should have not further affected the remanence. Furthermore, the K-Ar age of rhyolite, distributed in the western part of the basin, is reported to be $65.98 \pm 0.93 \mathrm{Ma}$ (Lee et al., 1992) coinciding with the timing of remagnetiza- tion in the study area. Similar aspects of remagnetization are observed in Youngdong basin lying in the southern boundary of the Ogcheon Belt (Cho, 1994). However, in order to understand more accurate mechanism of the remagnetization and to constrain the age of the remagnetization, geochemical studies of the temperature and chemical conditions of fluids and the timing of the fault development in the basin that might play an important role in the passage of the fluids are desirable.

\subsection{Age of granite}

The age of granite in the Eumsung basin is controversial. The granite in the west to the basin was originally assigned as Cretaceous in age according to the reported K-Ar age of $112 \mathrm{Ma}$ (Kim, 1971), while the age of the granite in the east of the basin is assumed to be Jurassic based on an intrusive relationship to the sedimentary rocks (Cheong et al., 1976). On the other hand, the same granite near the Jincheon area yielded an age of $194 \mathrm{Ma}$ by Rb-Sr method (Joo et al., 1979). However, Chun et al. (1994) recently argued that they found fault-contacts between the granite and the sedimentary rocks, thus the granite in the west should be Jurassic in age.

The paleomagnetic mean directions of the granites are compared to those from previous paleomagnetic studies. It is revealed that the mean direction of the east granite $(D / I=$ $\left.347.0^{\circ} / 47.7^{\circ}, k=40.2, \alpha_{95}=3.6^{\circ}\right)$ is similar to the Jurassic direction (mean $D / I=334.3^{\circ} / 51.0^{\circ}, \alpha_{95}=8.4^{\circ}$ ) obtained from granites in the Ogcheon Folded Belt by Kim and Van der Voo (1990). On the other hand, the paleomagnetic direction representing the granite in the west was compared with the paleomagnetic directions calculated for the study area $\left(127.61^{\circ} \mathrm{E}, 36.90^{\circ} \mathrm{N}\right)$ from the published pole positions of Early Cretaceous to Quaternary. It is found that the paleomagnetic direction of the granite in the west $\left(D / I=354.6^{\circ} / 59.5^{\circ}, k=9.1, \alpha_{95}=8.8^{\circ}\right)$, is similar to the Tertiary direction $\left(D / I=357.3^{\circ} / 55.0^{\circ}\right)$ calculated from the Tertiary pole position of Kim and Kang (1989) (Fig. 12).

Since the mean directions of the east and west granites are statistically different from each other, it is interpreted that the two granites were not magnetized at the same time. As described before, demagnetization features of the granite in the east are also different from those of the granite in the west in a way that the samples from the western part of the study area generally show unstable remanent directions and abrupt changes in intensity giving rise to difficulties to isolate the ChRMs, while the samples from the eastern part disclose stable remanent directions and gradual decrease of intensity resulting in better defined ChRMs (Fig. 3). Moreover it is revealed, based on the IRM acquisition results, that the major magnetic carrier of the granite in the west (site 35) is hematite, whereas magnetite is the predominant magnetic mineral of the granite in the east (Fig. 4(b)). In addition, electron microscope observations show that hematite is the dominant authigenic iron oxide mineral resulted from the alteration of pre-existing minerals in the granite from the west (Fig. 8(a)), indicating that the mean direction of the west granite is suspicious of being a remagnetized component. Moreover it is also possible that the ChRMs of the granite in the west of the basin are of VRM origin because lower coercivity components isolated at 5-15 $\mathrm{mT}$ demagnetization level are included. Thus, it is concluded that the age of the 


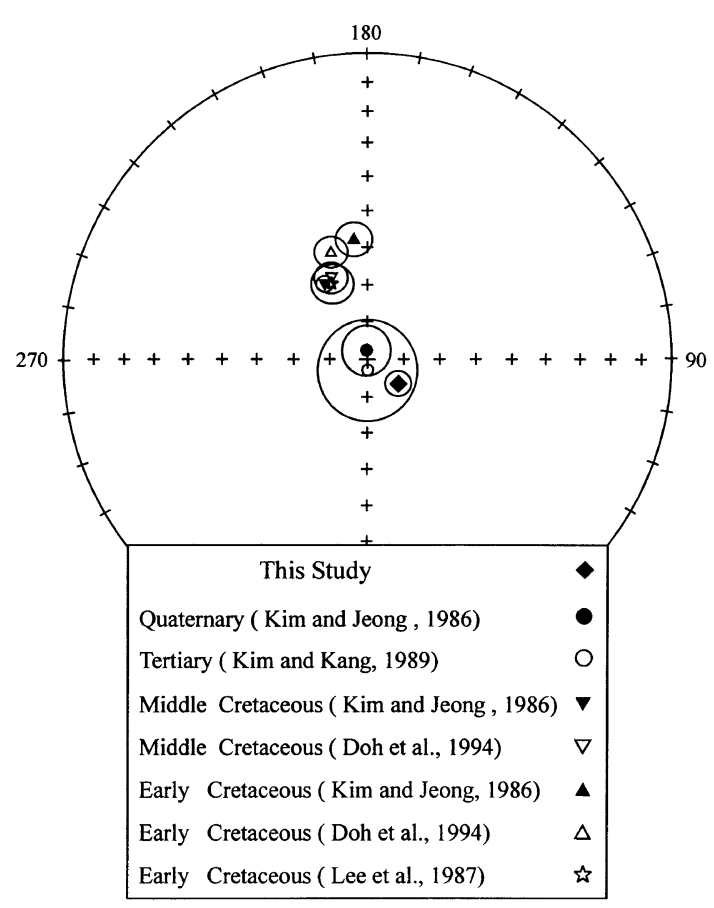

(a)

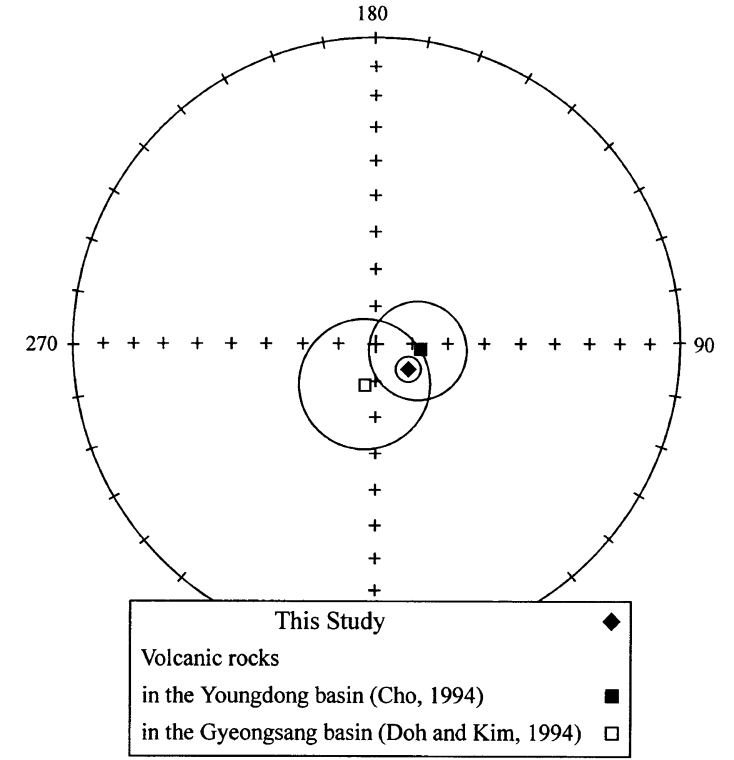

(b)

Fig. 11. Paleomagnetic pole of the Chopyeong Formation compared to (a) early Cretaceous to Quaternary poles obtained in Korea, and (b) those from volcanic rocks in the Youngdong and Gyeongsang basins.

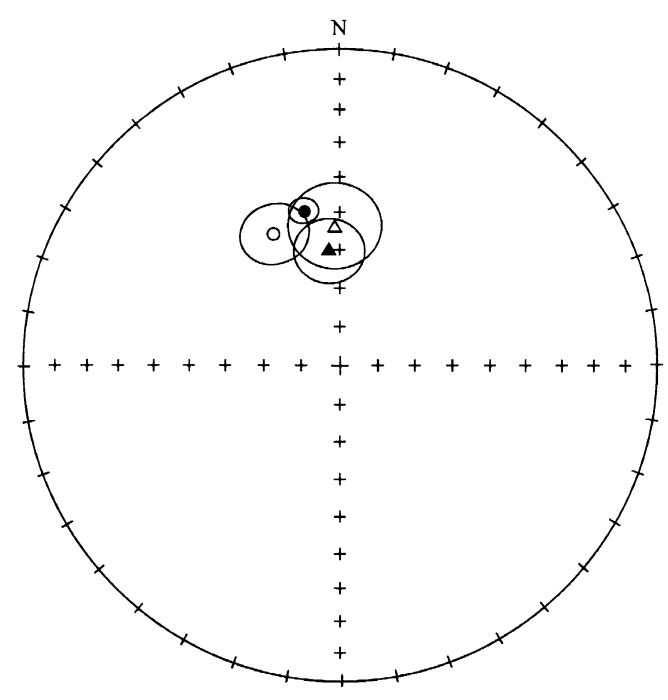

Fig. 12. Comparison of the characteristic directions of granites with $95 \%$ confidence circle. Solid circle: granite in the east to the Eumsung basin; solid triangle: granite in the west to the Eumsung basin; open circle: Jurassic granite $\left(D / I=334.3^{\circ} / 51.0^{\circ}\right)$ of Kim and Van der Voo (1990); open triangle: Tertiary direction $\left(D / I=357.3^{\circ} / 55.0^{\circ}\right)$ calculated for the study area $\left(127.67^{\circ} \mathrm{E}, 36.90^{\circ} \mathrm{N}\right)$ from Tertiary pole of Kim and Kang (1989).

granite in the east is Jurassic, leaving the age of the granite in the west undetermined. Yet, there remains the possibility that the directions of granites in the east and west to the basin are from the same population (i.e., same Jurassic direction), but weak intensity and instability of the remanence of the granite in west affect the distribution of magnetic directions resulting in the mean direction apart from the mean of the east granite.

\section{Conclusions}

1. It is concluded that the Chopyeong Formation has been remagnetized based on the fact that the mean direction at $20 \%$ untilting $\left(D / I=350.8^{\circ} / 57.9^{\circ}, k=177.9, \alpha_{95}=1.8^{\circ}\right)$ is more tightly clustered and the characteristic direction is significantly different from the directions obtained from the Cretaceous rocks in the Gyeongsang basin, although it is hard to determine whether the magnetization of the Chopyeong Formation was acquired during syntilting or not.

2. From the characteristics of remagnetization of the Chopyeong Formation in the Eumsung basin and electron microscope observations, it is evident that the strata acquired the chemical remagnetization due to the formation of secondary magnetic minerals under the influence of fluids presumably triggered by the igneous activities during late Cretaceous to early Tertiary.

3. It is revealed that the age of the granite in the east of the basin is Jurassic because the mean direction of the east granite $\left(D / I=347.0^{\circ} / 47.7^{\circ}, k=40.2, \alpha_{95}=3.6^{\circ}\right)$ is similar to the Jurassic direction of the Korea Peninsula. Although the paleomagnetic direction of the granite in the west to the basin $\left(D / I=354.6^{\circ} / 59.5^{\circ}, k=9.1, \alpha_{95}=8.8^{\circ}\right)$ is similar to the Tertiary direction, the age of the granite is left undetermined due to the weak intensity and instability of the remanence of the granite during demagnetization treatments. 
Acknowledgments. This study was supported by the Center for Mineral Resources Research sponsored by the Korea Science and Engineering Foundation. A package of computer programs used in this study was kindly provided by Dr. R. J. Enkin. We thank Wonnyon Kim for editing the manuscript. We thank Dr. Shibuya, Dr. Zhao, and an anonymous reviewer for constructive comments of the manuscript.

\section{References}

Butler, R. F., Paleomagnetism: Magnetic Domains to Geologic Terranes, 195 pp., Blackwell Scientific Publications, Boston, 1992.

Cheong, C. H., Y. A. Park, and H. M. Kim, Explanatory Text of the Geological Map of Eumseong Sheet (6724-IV), 32 pp., Korea Research Institute of Geoscience and Mineral Resources, 1976.

Cho, Y. Y., A paleomagnetic study of Cretaceous rocks from the Youngdong Basin, M.Sc. Thesis, 21 pp., Korea University, 1994.

Choi, S. J., B. C. Kim, H. Y. Chun, and Y. B. Kim, Charophytes from the Chopyeong Formation (Cretaceous) of the Eumsung Basin, Korea, $J$. Geol. Soc. Korea, 31, 523-528, 1995.

Chun, H. Y., Y. S. Choi, S. J. Choi, Y. B. Kim, B. C. Kim, B. S. Lee, and P. Y. Bong, Fossil Floral and Faunal Assemblages and Paleoenvironmental Modelling Study on the Cretaceous Sedimentary Basins Scattered in/near the Ogcheon Belt, Annual Rep., KR-94(T)-11, 1994.

Day, R., M. Fuller, and V. A. Schmidt, Hysteresis properties of titanomagnetite: grain-size and compositional dependence, Phys. Earth Planet. Inter. 13, 260-267, 1977.

Doh, S. J. and K. H. Kim, A paleomagnetic study of Cretaceous rocks from the Euiseong area, Econ. Environ. Geol., 27, 263-279, 1994

Doh, S. J., C. S. Hwang, and K. H. Kim, A paleomagnetic study of sedimentary rocks from Kyeongsang Supergroup in Milyang Sub-Basin, $J$. Geol. Soc. Korea, 30, 211-228, 1994.

Elmore, R. D. and C. McCabe, The occurrence and origin of remagnetization in the sedimentary rocks of North America, Rev. Geophys., suppl. (IUGG report), 29, 377-383, 1991

Fisher, R. A., Dispersion on a sphere, Roy. Soc. (London) Proc. Ser. A, 217, 295-305, 1953.

Hudson, M. R., R. L. Reynolds, and N. S. Fisherman, Synfolding magnetization in the Jurassic preuss sandstone, Wyoming-Idaho-Utah Thrust Belt, J. Geophys. Res., 94, 13,681-13,705, 1989.

Ito, $\mathrm{H}$. and $\mathrm{K}$. Tokieda, An interpretation of paleomagnetic results from Cretaceous granites in South Korea, J. Geomag. Geoelectr., 32, 275-284, 1980.

Joo, S. H., D. J. Lee, and D. H. Kim, Rb-Sr Age Dating of the Granite in the Choengju Area, Investigate Rep., 6, 111-131, 1979.

Kang, P. C., W. Y. Kim, and C. H. Lee, Explanatory Text of the Geological Map of Jinchon Sheet (6724-1), 16 pp., Korea Research Institute of Geoscience and Mineral Resources, 1980.

Kent, D. V., Thermoviscous remagnetization in some Appalachian limestones, Geophys. Res. Lett., 12, 805-808, 1985.

Kim, I. S. and H. C. Kang, Paleomagnetism of Tertiary rocks in the Eoil Basin and its vicinities, Southeast Korea, J. Geol. Soc. Korea, 25, $273-$ 293, 1989.

Kim, I. S., H. K. Lee, H. Yun, and H. C. Kang, Paleomagnetism of Cretaceous rocks in the Uisong Area, Kyongsang Basin, Korea, J. Korean Inst. Mining Geol., 26, 403-420, 1993.

Kim, K. H. and B. I. Jeong, A study on the paleomagnetism of Southern Korea since Permian, J. Korean Inst. Mining Geol., 19, 67-83, 1986.

Kim, K. H. and D. S. Kim, Magnetostratigraphy of the Chaeyaksan, Konchonri, and Jusasan Formation distributed in Taeku-Kyongju area, J. Geol. Soc. Korea, 27, 40-51, 1991.

Kim, K. and R. Van der Voo, Jurassic and Triassic paleomagnetism of South Korea, Tectonics, 9, 699-717, 1990.

Kim, O. J., Timing of intrusion and tectonic movement of granite in the South Korea, J. Korean Inst. Mining Geol., 4, 1-9, 1971.

Kirschvink, J. L., The least square line and plane and the analysis of paleo- magnetic data, Geophys. J. R. Astr. Soc., 62, 699-718, 1980.

Lee, C. H. and J. H. Kim, Explanatory Text of the Geological Map of Jeungpyeong Sheet (6724-III), 16 pp., Geological Survey of Korea, 1971.

Lee, G. D., J. Besse, and V. Courtillot, Eastern asia in the cretaceous: New paleomagnetic data from South Korea and a new look at Chinese and Japanese data, J. Geophys. Res., 92, 3580-3596, 1987.

Lee, H. Y., H. S. Yun, and J. D. Lee, Geological Report of the Pyongchon Sheet, 15 pp., KIER, 1989

Lee, M. W., C. K. Won, and K. H. Kim, The cretaceous volcanic activities and petrology in Kyonggi Massif-on the Kapcheon, Eumsung and Kongju Basin, J. Geol. Soc. Korea, 28, 314-333, 1992.

MacFadden, P. L. and D. L. Jones, The fold test in palaeomagnetism, Geophys. J. R. astr. Soc., 67, 53-58, 1981.

McCabe, C., R. Van der Voo, C. R. Peacor, C. R. Scotese, and R. Freeman, Diagenetic magnetite carries ancient secondary remanence in some Paleozoic sedimentary carbonates, Geology, 11, 221-223, 1983.

McElhinny, M. W., Statiscal significance of the fold test in paleomagnetism, Geophys. J. R. astr. Soc., 8, 338-340, 1964.

Min, K. D., O. J. Kim, S. K. Yun, D. S. Lee, and S. H. Joo, Applicability of the plate tectonics to the post-late Cretaceous igneous activity and mineralization in the southern part of south Korea (I), J. Korean Inst. Mining Geol., 15, 123-154, 1982.

Oliver, J., Fluids expelled tectonically from orogenic belts; Their role in hydrocarbon migration and other geologic phenomena, Geology, 14, 99102, 1986.

Otofuji, Y., J. Y. Oh, T. Hirajima, K. D. Min, and S. Sasajima, Paleomagnetism and age determination of Cretaceous rocks from Gyeongsang Basin, Korean Peninsula, in The Tectonic and Geologic Evolution of Southeast Asian Seas and Islands, II, edited by D. E. Hayes, Geophys. Monogr. 27, pp. 388-396, Am. Geophys. Union, 1982.

Otofuji, Y., K. H. Kim, H. Inokuchi, H. Morinaga, F. Murata, H. Katao, and K. Yaskawa, A paleomagnetic reconnaissance of Permian to Cretaceous sedimentary rocks in southern part of Korean Peninsula, J. Geomag. Geoelectr., 38, 387-402, 1986.

Otofuji, Y., K. Katsuargi, H. Inokuchi, K. Yaskawa, K. H. Kim, D. S. Lee, and H. Y. Lee, Remagnetization of Cambrian to Triassic sedimentary rocks of the Paegunsan Sycline of the Okch'on Zone, South Korea, J. Geomag. Geoelectr., 41, 119-135, 1989.

Piper, J. D. A., Palaeomagnetism and the Continental Crust, 91 pp., Open University Press, Milton Keynes, 1987.

Pullaiah, G., E. Irving, K. L. Buchan, and D. J. Dunlop, Magnetization changes caused by burial and uplift, Earth Planet. Sci. Lett., 28, 133 $143,1975$.

Suk, D. W., R. Van der Voo, and D. R. Peacor, Scanning and transmission electro microscope observations of magnetite and other iron phases in Ordovician carbonates from east Tennessee, J. Geophys. Res., 95, 12,327$12,336,1990$

Thompson, R., J. Bloemendal, J. A. Dearing, F. Oldfield, T. A. Rummery, J. C. Stober, and G. M. Turner, Environmental applications of magnetic measurements, Science, 207, 481-486, 1980.

Walker, T. R., E. E. Larson, and R. P. Hoblitt, Nature and origin of hematite in the Moenkopi Formation (Triassic), Colorado Plateau: A contribution to the origin of magnetism in red beds, J. Geophys. Res., 86, 317-333, 1981

Watson, G. S. and R. J. Enkin, The fold test in paleomagnetism as a parameter estimation problem, Geophys. Res. Lett., 20, 2,135-2,137, 1993.

Won, C. K., M. W. Lee, J. H. Noh, and H. K. Lee, Cretaceous volcanic activity in Tongri Basin, J. Geol. Soc. Korea, 30, 542-562, 1994.

Zijderveld, J. D. A., AC demagnetization of rocks: Analysis of results, in Method in Paleomagnetism, edited by D. W. Collinson, K. M. Creer, and S. K. Runcorn, pp. 254-286, Elsevier, Amsterdam, 1967.

S.-J. Doh (e-mail: sjdoh@kuccnx.korea.ac.kr), D.-W. Suk, and B.-Y. Kim 